Corporate and State Governance in Mining and Forestry 



\section{Global Capital and Local Ownership in Solomon Islands' Forestry Industry}

\section{Tarcisius Tara Kabutaulaka}

As humanity ventures further into the 21 st century, we are constantly being reminded of how global forms and processes have reached even the most remote corners of the world. This is what, in contemporary mantra, is referred to as 'globalisation' - the term used to describe the increasing integration of global communities.

In the past decade there has been considerable inquiry into the origins, nature and impact of globalisation, and the threats and opportunities it offers. Even its most resolute critics would admit that the forms and processes that encompass globalisation have reached even the most isolated corners of the globe. Today, for example, it is not unthinkable that children in relatively remote places such as the Weather Coast of Guadalcanal in Solomon Islands have tasted Coca-Cola and can buy it from a village store, the same product that can be bought from a 7-Eleven shop at a street corner in New York. This interaction between the 'global' and the 'local' was dramatically illustrated in the 1980 film The Gods Must Be Crazy, in which Xi, a Kalahari Bushman, encounters technology for the first time in the form of a Coke bottle. He takes it back to his people and they use it for many tasks. But when they start fighting over it, he decides to return it to the gods, from whom he thinks it has come. In his quest to throw the bottle over the edge of the Earth, Xi encounters Western 'civilisation' and is fascinated and captured by it. In the process, Xi also influences Western perceptions about Kalahari Bushmen, their deep and complex knowledge of the bush, their ability to survive in it, and their innovative use of the Coke bottle.

Similarly, in many cases, the more local communities attempt to resist globalisation and 'throw its evils over the edge of the Earth', the more they engage with it. Understanding how the global and the local interact is vital for helping local communities formulate strategies to deal with and benefit from globalisation. This chapter uses natural-resource development to explore the interaction between global forces and local communities. It examines how local communities react to global forces, with a focus on the Pacific Islands and Melanesia, with particular reference to Solomon Islands' forestry industry.

Here, I assert that local communities are not simply passive victims of global forces. Rather, they actively interrogate, negotiate, strategise and engage with global forms and processes, and use them to meet local needs and demands. This assertion is based on the premise that Melanesian societies, rather than being 
the 'traditionalised', static and timeless entities that conventional anthropology sometimes presents them to be, are dynamic and engaging. I am not suggesting that there is an equal power relationship between the local and global. Of course, the power relationship is often tipped in favour of the global, but the local is not always simply a passive victim of globalisation.

\section{Global capital and local resources}

Transnational corporations driven largely by the desire to maximise profit are among the most aggressive agents of globalisation. They create and transfer capital, ideas, languages, cultures, values and ways of life across national, ethnic and linguistic boundaries. In the process, they integrate societies around the world into the cash economy, the backbone of the capitalist system, which pushes global forms and processes to remote parts of the globe.

This is vividly illustrated by the documentary film Advertising Missionaries (Aspire Films 1996), which shows how theatre is used to advertise and introduce Western goods to previously 'untouched' villages in the remote Highlands of PNG. Behind the Papua New Guinean actors are transnational corporations which own the products and ensure they reach anyone who has the potential to make and spend money. To acquire these products, people in isolated parts of the globe - like those in the Highlands of PNG - have to participate in the cash economy by allowing goods and capital from industrialised countries to flow into their communities. This is often facilitated by the export of Western media - including television programs and popular culture/music - that promote the 'large-scale transfer of meaning systems and symbolic forms' (see Hannerz 1997: 107) and in turn transform cultures and consumption habits. For many of these communities the only way that they could have access to the cash economy is to sell their labour and natural resources.

History is littered with stories of how cheap labour from developing countries has been used to support industries that are registered and based in developed countries, or owned by people who live in industrialised countries. It was, for example, the massive export of African, Asian and Pacific Islander labourers to the Americas, the Caribbean, Australia and other Pacific Islands such as Fiji, Samoa and Hawai'i in the 17th, 18th and 19th centuries that supported plantation industries vital for the production of capital that later became the force pushing contemporary global forms and processes. Horton and Horton (2005: 7) provide an insightful account of how African labour in the form of slaves 'played a profoundly important role in the making of the United States'. Similarly, it was labourers from the 'South Seas' - Solomon Islands, Vanuatu and PNG — who were used in the development of sugarcane plantations in Queensland, Australia (Moore et al. 1990). Indian labourers were shipped to Fiji and the Caribbean to work in the sugarcane plantations (Lal 2004; Mintz 1995). 
Labour from developing countries continues to play an important role in the production and transfer of goods and capital. It is, for instance, common for businesses to take advantage of cheap labour in developing countries through outsourcing arrangements. In the USA, for example, it is widely known that the person who answers the phone at a call centre might be located in Bangalore, India. Similarly, most of the goods sold in Wal-Mart shops are produced in China, using cheap Chinese labour. Recently, the host of The Tonight Show, Jay Leno, commented that one of the few positions in the USA not yet outsourced was the country's Presidency. Such comments might be humorous, but they illustrate the significance of outsourcing in our contemporary world.

Much of the world's labour has been used for the extraction and development of natural resources such as oil, minerals, timber, fisheries and the cultivation of land for large-scale plantation agriculture. A significant percentage of the natural resources needed to sustain the capitalist market economy are located in Africa, Asia, the Caribbean and Oceania. In 2005, for example, the sub-Saharan countries of Africa exported about 1.5 million barrels of oil a day to the USA and Canada and 700,000 barrels a day to Europe to keep the industries of those places afloat and to sustain their mass-consumption societies (Kotch 2005: 56). On the other hand, much of the capital invested in the mining of oil from countries such as Nigeria, Angola, Gabon, Sudan, Chad and Congo is from American oil giants such as Chevron and Exxon Mobil. Similarly, most of the transnational companies that extract oil and mineral resources in South American countries such as Venezuela, Bolivia, Chile, Mexico and Peru originate from North America and Europe.

In the Pacific Islands it is Australian companies that dominate the mining industry in PNG, Solomon Islands and Fiji, while Japanese-, Korean- and Taiwanese-registered companies dominate the fisheries industry. Malaysian and Korean companies dominate the forestry industry. In PNG the recently established Gas to Queensland (GTQ) project at Kutubu is led by Chevron, the US petroleum giant (Tiensten 2001: http://www.pomcci.org.pg/hiri2001/Tiensten.doc, accessed on February 9, 2006). Large-scale oil palm, coconut and cocoa plantations were originally dominated by British companies such as Levers Brothers, but are increasingly being taken over by Australian and Asian companies.

This has led to many developing countries becoming economically dependent on foreign capital for the extraction and export of natural resources. Sub-Saharan countries such as Nigeria and Angola, for example, have become heavily dependent on oil exports to North America, Asia and Europe. In recent years, '[t]hree factors - rising global demand for oil, increasing deepwater reserves off West Africa, and threats to oil supplies from the Middle East - have pushed both North America (mainly the USA) and Asia (mainly China) to import more oil from sub-Saharan Africa' (Kotch 2005: 56). 
Similarly, many Pacific Island countries, especially the relatively larger Melanesia countries, are economically dependent on natural resources. Development plans in these countries are tied to the availability and exploitation of natural resources. For many remote communities, natural-resource exploitation is often the only source of income generation. Hence, activities such as mining and logging are often accepted as the way forward in the development process, and communities close to these large-scale natural-resource development projects are greatly influenced by them. Discussions of globalisation and the Pacific Islands highlight the importance of transnational corporations in natural-resource development (Lockwood 2003; Firth 2000).

In the past two decades the flow of capital to developing countries for purposes of natural-resource development has been exacerbated by the push for economic liberalisation, which encourages - and in some cases forces - countries to not only open their markets but allow foreign investors to exploit their natural resources. This is pitched as a necessary part of the development process.

For Pacific Island countries, access to natural resources for large-scale commercial development is often complicated by the fact that land and inshore fisheries are communally owned. This communal ownership and control of resources is in many cases recognised and protected by law. In the Melanesian countries of PNG, Solomon Islands and Vanuatu, for example, this is recognised as 'customary' ownership. In Solomon Islands, more than 80 per cent of land is 'customarily' owned. This means that potential investors have to deal with not only the State and individual owners, but with entire communities before any natural-resource development initiative can take place. Anyone who has ever been associated with natural-resource development in the Pacific Islands would attest to the number of people and the multitude of interest groups that need to be consulted. Hence, while global capital is important, local communities, because of their ownership of land and inshore fisheries, can influence how their resources are exploited. This is not to suggest that they have, in the past, done so successfully. Rather, it is to say that given appropriate capacity they have the potential to influence the processes and outcomes.

In realising the potential power that they have, landowning communities often mobilise themselves primarily to maximise resource rent. How they mobilise themselves and the way they use resource rents have been the subjects of much discussion (see Hviding and Bayliss-Smith 2000; Turia 2003; Ernst 1999; Filer 1997; Foale 2000; Golub 2004).

In this discussion it is important to note that 'local communities' are not always a homogeneous entity, existing in harmony. Rather, they are often a dynamic group with members who have varying interests and degrees of exposure to the world. There are women, children, elders, those with formal education, government officials, aspiring big-men, con-artists, etc. In some cases, 
landowning communities reorganise themselves in order to deal successfully with corporate powers (see Ernst 1999; Fa'anunu unpublished; Filer 1998; Foale 2000; Gerritsen and Macintyre 1991; Golub 2004). Rather than simply watch global forces take over their societies, local communities (either collectively or as individuals) react to and come to terms with these global forces.

We often equate globalisation with the expansion of Western ideas, cultures, values, lifestyles, technology, people and capital. Increasingly for many Pacific Island countries, however, globalisation also involves the flow of people, ideas, cultures, values, technology and capital from Asia. It is, for example, Asian people, capital and markets that dominate the Solomon Islands forestry industry.

\section{Solomon Islands forestry: A brief background}

Commercial logging started in Solomon Islands in the 1920s. Bennett documents the story of the Vanikoro Kauri Timber Company (VKTC), an Australian-owned company, that harvested kauri timber (Agathis macrophylla) on Vanikoro Islands in the eastern Solomons from 1926 until 1964. During that period the company struggled to make a profit, and eventually closed its operations and left due to the high cost of production and transportation, and restrictions on access to potential markets (see Bennett 2000a).

Large-scale commercial logging is, however, a recent phenomenon. As Frazer (1997a: 45) notes, in the past three decades there have been two distinct regimes, 'each marked by differences in the ownership and location of the forests being harvested, the number and size of the companies engaged in export logging, and government management of the industry'. The first was from 1963 to the early 1980s, when most logging took place on government land, or customary land leased by government. During this period, under the Colonial Government's Timber Ordinance, it was the Government that had the responsibility for acquiring land and giving logging licences to companies interested in harvesting timber. At that time the British-registered company Levers Pacific Timber (a subsidiary of Levers Brothers) monopolised the timber industry, accounting for about 75 per cent of log production (Bennett 1998: 2).

The second period began in the early 1980s and continues today. This period is marked by a shift from government land to customary land and an influx in the number of foreign (especially Asian) companies with logging concessions. Between 1981 and 1983, for example, the number of foreign companies with logging licences increased fourfold (Frazer 1997a: 46). The beginning of this period coincided with an event that marked an important turning point in the history and development of the logging industry in Solomon Islands: in 1982, Levers Pacific Timbers' logging camp and equipment at Enoghae on New Georgia in the Western Province were destroyed by landowners opposed to the company's operations. This led to the subsequent establishment of the North 
New Georgia Timber Corporation Act, which allowed customary landowners to set up logging companies (Tausinga 1989). The Enoghae incident demonstrated the displeasure of local landowners and their leaders with attempts by the Government to facilitate the allocation of logging rights on customary land to Levers. The Forest and Timber Amendment Act (1977) had recognised the customary landowners' rights to the forest and their ability (albeit via the cumbersome process of adjudicating claims to rights by the Area Council) to allocate these within the process. The North New Georgia Act enhanced this recognition of landowners' authority over land and forestry resources (Tausinga 1989).

Figure 1. Log production, export and estimated sustainable yield for natural forest (CBSI log export records; Forestry Review 1995; ADB 1998)

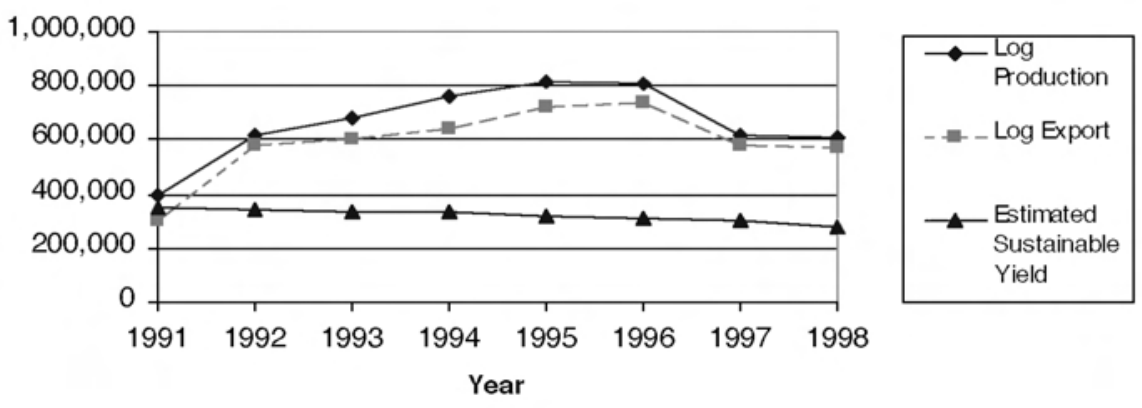

This period also coincided with the first Solomon Mamaloni Government's time in office. This was a government known for its pro-logging policies, which encouraged Asian companies to invest in the logging industry. The Mamaloni Government pushed for a shift away from a concentration on Western investors to 'looking north' towards Asia. The Government also wanted to encourage landowners' active participation in the industry (Bennett 2000; Frazer 1997).

This period was also characterised by a rapid increase in log production. In 1989 the volume of log production was about 300,000 cubic metres as compared with about 700,000 and 800,000 cubic metres in 1993 and 1996 respectively (see Figure 1). This rapid increase was due to an increase in the number of logging companies with logging concessions, a shift into customary land, the increasing demand for hardwood timber in international (particularly Asian) markets, an increase in the price of hardwood timber, and Solomon Islands' increasing economic dependence on log exports (Duncan 1994; Price Waterhouse 1995).

The rapid increase in log production led to harvests going beyond the estimated sustainable yield. In 1992, for instance, it was estimated that about 13 million cubic metres of commercial timber was harvestable using conventional logging methods. By the mid-1990s, production was way above the potential sustainable 
yield. Log production in 1994 and 1995, for example, was 735,000 and 826,000 cubic metres respectively. These figures were more than double the potential sustainable yield for those two years, of 294,896 and 275,710 cubic metres respectively (CBSI 1996). If these levels of log production continued, it was estimated that the logging industry would not be sustained for another decade (Montgomery 1995; Price Waterhouse 1995; Frazer 1997).

Predicting the depletion of forests is, however, not an exact science. In 2005, nearly a decade later, authorities were saying that forests would be depleted in 15 years if harvested at the current rate, which was higher than it was in 1997 (CBSI 2006).

\section{Figure 2. Log volume to major export destinations 1994-1998 (Log export data from CBSI.)}

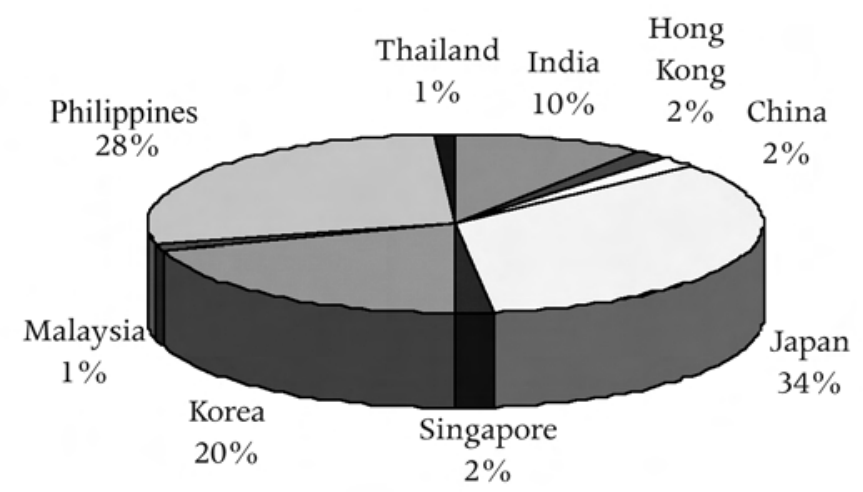

In 1997 there was a sudden decline in log production, due mainly to the Asian economic crisis and the collapse of Asian timber markets. This was especially serious because of Solomon Islands' dependence on the Asian log markets (see Figure 2). The ADB (1998: 54) estimated that the volume of log production in 1996 was 811,000 cubic metres while in 1997 it dropped to 637,000 cubic metres (see Figure 1).

Despite the decline in production, the Central Bank of Solomon Islands (CBSI) reported that in 1998 the volume of logs harvested from natural forests did not drop to the extent anticipated at the beginning of that year and was still well above the estimated sustainable level. For instance, while the volume of timber harvested from natural forests in 1998 was estimated to be about 640,000 cubic metres, the predicted sustainable yield was about 220,000 cubic metres. This was attributed mainly to the 20 per cent devaluation of the Solomon Islands dollar in December 1997, which 'positively impacted on exporters' balance sheets, government's preferential taxes for stockpile exports, and partial recovery 
in the market that raised the average price for Solomon Islands' logs from a trough of US\$45 [\$A60] per cubic [metre] to US\$80 [\$A108] per cubic [metre] towards the end of 1998' (CBSI 1999: 15).

By 2000, most of Solomon Islands' major industries were affected by the civil unrest, which started in late 1998 (see Fraenkel 2004; Moore 2005). The Solomon Islands Plantation Limited (SIPL) oil palm plantation stopped operations in June 1999. A year later, in mid-2000, the Gold Ridge mine on Central Guadalcanal also suspended operations after militants took over the mine site and threatened workers.

In the first year of the civil unrest, the forestry sector was not as severely affected as other sectors. The CBSI reported that this was because 'the Western and Isabel provinces are the major hosts to logging operations and therefore while logging on Guadalcanal ceased for some time, or [was] operating at below capacity, the overall output actually rose' (CBSI 2000: 16). In 1999, because log production data were not available, the CBSI used export shipment data to make estimations: about 624,000 cubic metres of logs were exported, up by 3 per cent on the previous year.

By March 2000, however, log production declined. This was attributed to the deteriorating security situation, which had by then affected other parts of the country, especially the high log production areas such as the Western and Choiseul Provinces. The Commissioner of Forests, Peter Sheehan, quoted in March 2000 a harvest rate of 550,000 cubic metres per annum (Sheehan 2000). This was well below the 624,000 cubic metres of the previous year, but still well above the expected sustainable harvest rate of 250,000 cubic metres per annum.

The claim that forests would be depleted in less than a decade if current logging practices were maintained was disputed by the Solomon Islands Forest Industries' Association (SIFIA). In January 1997, SIFIA showed a video documentary produced for the purpose of what Eric Kes, the then Executive Director of SIFIA, described as correcting 'widespread misconceptions about the Solomon Islands forest industry sector, which have often resulted in misinformed and emotion[al] criticism[s] of the industry and government, both locally and abroad' (Solomon Star, January 29, 1997). The underlying argument in the video was that while close to 80 per cent of Solomon Islands' land was covered by forests, only about 12 per cent was suitable for commercial logging operations. Kes stated that 'the often used stereotype of total forest destruction is simply untrue' (Solomon Star, January 29, 1997). In a printed document released by SIFIA along with the video, Kes argued that 'approximately 10 per cent have been previously logged, but are not, as often argued, completely destroyed, but will generally recover and can be re-harvested over the years'. The document also asserted that 80 per cent of Solomon Islands' natural forest would never be subject to large-scale commercial logging. 
Apart from unsustainable log production, another issue that dominated discussions of the forestry industry was Solomon Islands' economic dependence on log exports. In 1990, logging contributed 34.5 per cent of the country's total exports. This increased to 54.9 per cent in 1993. In 1994, it contributed 56 per cent of the country's export earnings and 31 per cent of all government earnings (Montgomery 1995). In the 10 years between 1988 and 1998, timber made up a huge percentage of Solomon Islands' principal exports (see Figure 3). From 1992 to 1996, receipts from log exports increased dramatically and dominated total exports. The average value of timber exports in that period was \$SI285.2 million per annum. In 1998, however, there was a dramatic decline in log export receipts: \$SI196.3 million compared with \$SI290.7 million in 1997 and an average of \$SI285.2 million in the period from 1993 to 1996 (CBSI 1999: 25). The 1997 and 1998 declines were due to the fall in export prices and volume as a result of the continued adverse developments associated with the Asian financial crisis. Despite this decline, the value of log exports was still well above that of other commodities (CBSI 1999: 25-6; see Figure 3).

Figure 3: Export values of principal commodity groups (CBSI data on value of exports by commodity)

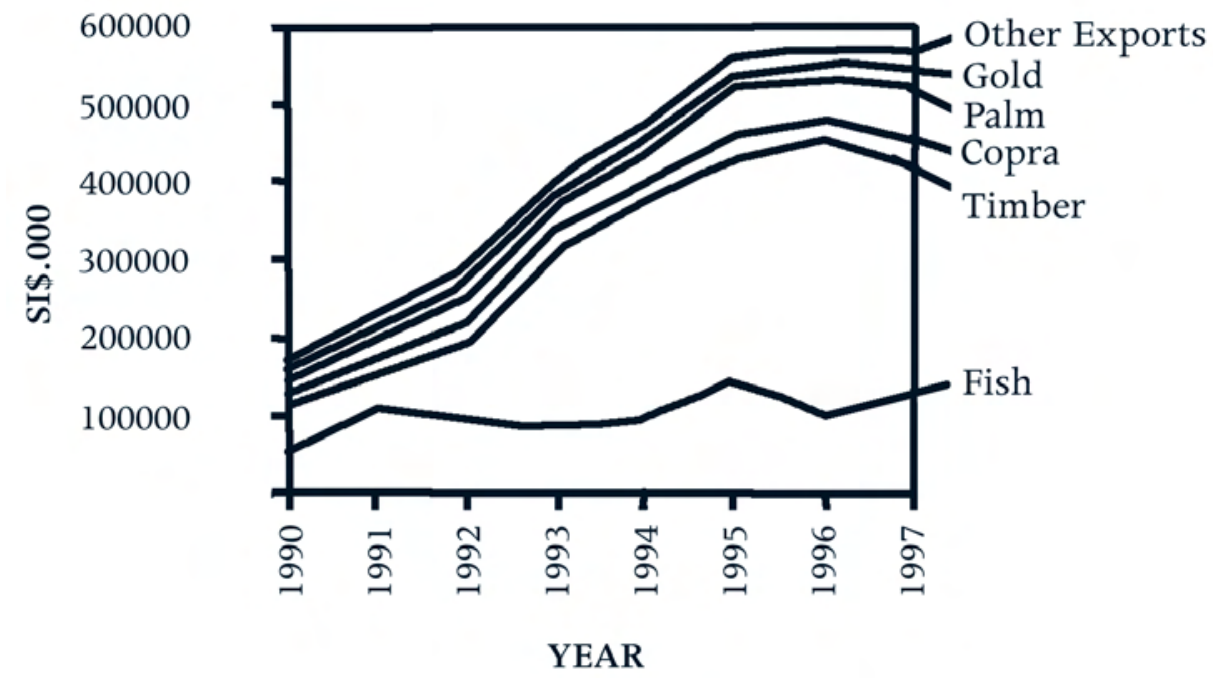

There was also concern that unsustainable harvest rates would cause severe economic and financial disruption when the commercially accessible forests were depleted. The ADB asserted that if timber production was reduced to meet the sustainable level by 2000, then, although it would involve some short-term disruption as government and the economy adjusted to lower levels of forest revenue, 'the forest resources would remain a source of revenue in perpetuity' (ADB 1998: 66). The bank presented three possible scenarios for managing the 
natural forest: i) continue at about the current harvest rates; ii) allow harvest rates to rise to a new maximum level potentially set by logical constraints on harvest operations; or iii) implement sustainable yield levels by 2000 . The ADB proposed that the 'government should carefully consider the harvest level options, which are likely to actually fall within the range between scenarios 1 and 3' (ADB 1998: 66).

Because of the country's dependence on log exports, the negative developments of 1997 and 1998 had an impact on the rest of the economy, contributing to a decline of about 7 per cent of Solomon Islands' real GDP in 1998 compared with an estimated growth of 3 per cent in 1997. This had an adverse impact on the country's economy.

Further, despite increasing log exports, in the late 1990s actual revenue collected from log exports declined. The Solomon Star reported on April 4, 1996, that although the value of round log exports in 1995 increased by \$SI16.7 million, the amount collected in export duties by the Government fell by $\$$ SI12.6 million. This signified weaknesses in Solomon Islands' tax system, which meant that the Government was unable to collect potential revenue. Price Waterhouse (1995) discussed the deficiencies of the tax system and highlighted the need for trained manpower and an improved administrative and monitoring system to enable the Government to capture much needed revenue. If that were not done the country was bound to lose enormous amounts of money through potential lost revenue.

Apart from the weaknesses of the tax collection mechanism, a substantial amount of potential revenue was also lost as a result of inefficient government policies. One such policy was the granting of duty remissions to log-exporting companies. This increased significantly in 1995 and 1996. As a result of these remissions, lost government revenue from 1995 to 1997 was \$75 million (ADB 1998: 59). This is a dramatic increase, compared with about $\$ 34$ million of potential revenue forgone in 1994 (Duncan 1994).

The duty remissions were given largely to landowner companies with the intention of assisting them to participate in the logging industry and encouraging them to invest in domestic processing. Most of these landowner companies have contractual agreements with foreign-registered companies because they do not have the financial capital or technology to extract and process logs on their own.

Price Waterhouse (1995) asserted that subcontractor agreements were either fixed at a rate per cubic metre of logs exported, irrespective of free-on-board (f.o.b.) value, or accepted a percentage share of the f.o.b. price, which is the price calculated without charge for delivery to the ship. Consequently, it was concluded that although most landowner companies received a share of the forgone tax revenue, 'the logging contractors are capturing up to 77 per cent of 
this' (Price Waterhouse 1995: 35) because of the structure of the contractor/landowner company agreements.

Further, logging companies evaded taxes because of a poor taxation system in the country. Dauvergne (1998-99: 8) discussed how structural defects in Solomon Islands' timber management policies enabled 'multinational investors to operate with remarkably poor harvesting and environmental standards, and make windfall profits'. Price Waterhouse (1995) reported that insufficient finance and lack of technical and human resources to monitor logging operations meant that it was difficult to implement the state's forestry policies, especially environmental rules. Further, there is evidence that companies used transfer pricing and made informal agreements (between buyers and producers) to ensure they benefited from the timber industry. By comparing Solomon Islands' import clearance records into Japan and the Republic of Korea with Solomon Islands' log exports for the first half of 1995, Price Waterhouse (1995) concluded that under-invoicing had reduced declared f.o.b. prices by at least \$A108 per cubic metre after reasonable allowances for freight and insurance. FORTECH (1995c) compared log export volume and value from Solomon Islands with log import volume and value to Japan and the Republic of Korea, and found that while for 1994 export and import volumes essentially correlated, after providing allowances for freight and insurance, sales to Japan were under-invoiced by about \$A46 per cubic metre and to Republic of Korea by $\$ A 43$ per cubic metre. According to Price Waterhouse (1995), under-invoicing is a common method of minimising taxation payments and that 'to claim that under-invoicing does not exist in Solomon Islands would make this country unique among log exporting countries around the world'.

Economic surplus forgone from 1990 to 1997 as a result of transfer pricing was estimated to be about $\$ 481$ million, compared with the $\$ 131$ million lost through under-taxation. The Government's cumulative recurrent budget deficit for the same period was an estimated \$295 million (ADB 1998: 71).

By the mid-1990s, there was widespread awareness of and concern (locally and internationally) over the issues confronting forestry developments in Solomon Islands. The Australian Government, for example, criticised the Mamaloni Government's policy on logging, and, to back its criticism, in 1996 it cut back aid to Solomon Islands and stopped funding the Timber Control Unit Project of the Forestry Division, set up to monitor the rate of logging. The EU also threatened to stop its funding of projects 'if the government failed to address forest management concerns' (Solomon Star, April 2, 1996). From 1998, however, AusAID revived its funding of government efforts to monitor and regulate the forestry industry, through the Solomon Islands Forest Management Project.

Because of the issues raised above, it was realised that the Government needed to develop policies that provided a coherent framework for developing the 
forestry sector. The ADB (1998: 76) suggested that, because of the cross-sectoral impact of these activities, developing forestry policy should be part of the broader public sector policy reform process. It also suggested that a subregional approach (through the Melanesian Spearhead Group) aimed at improving resource rent capture should be established. This suggestion was not taken up.

Because of widespread awareness of the problems associated with the logging industry, Francis Billy Hilly's National Coalition Partnership (NCP) Government, which came to power in mid-1993, attempted to introduce policies to reform the timber industry. In July 1993, for instance, the NCP Government announced plans for increased local processing and the phasing out of large-scale logging in favour of eco-forest logging. A Timber Control Unit was established within the Ministry of Forests to monitor timber production. The effort of the NCP Government was thwarted after its collapse in 1994. It was alleged that logging companies opposed to forestry reforms had a hand in its collapse (Bennett 2000: 340-4).

Another attempt to reform the forestry sector was the Bartholomew Ulufa'alu Government's introduction of the Forestry Act 1999, which, despite being tabled in Parliament, was never gazetted. The Ulufa'alu Government's initiatives, however, suffered a setback when Ulufa'alu was forced to resign as Prime Minister after the Malaita Eagle Force coup of June 5, 2000.

The collapse of the Asian economies and log markets gave the Government an opportunity to re-evaluate the industry. By late 1997 there was a drop in demand and price for Solomon Islands logs. The CBSI (1998: 26) reported that from 1992 to 1996, the period of the logging boom, the annual average export price had been more than \$A160 per cubic metre. In 1997 and 1998, however, this fell dramatically to an average of $\$ A 140$ and $\$ A 80$ per cubic metre, respectively. These included prices for plantation logs (about $\$ A 86$ per cubic metre), which are lower than for natural forest logs (CBSI 1998: 18).

The collapse in demand and price for logs caused a corresponding decline in log exports. In 1998 an estimated 604,000 cubic metres of round logs were exported compared with 650,124 cubic metres in 1997, and 811,000 cubic metres in 1996 (see Figure 1). The total value of shipments amounted to \$A93 million in 1997, dropping from \$A124 million in 1996. The value of log shipments in 1998 came to $\$ A 48.5$ million, down by 47 per cent from the previous year, reflecting the subdued demand in Asia for much of the year (CBSI 1999: 15). However, as noted above, there was a rise in production in 1999 that corresponded with the improvement of Asian economies, especially log markets in Korea, Japan and the Philippines.

The Asian economic crisis and the collapse of log markets caused many logging companies to stockpile. At the end of 1997 the volume of log stockpiles reached 300,000 cubic metres and uncollected logs left in the jungles were estimated by 
the Ministry of Forestry, Environment and Conservation (MFEC) to number about one million cubic metres.

\section{Logging and local communities}

Drawing from the above story, let us now explore how the Solomon Islands forestry industry and the global forces associated with it interacted with local communities. In this exploration, it is important, as Lockwood notes in relation to the Pacific Islands more generally, to understand not only what motivates foreign interests, but what motivates local people 'as they encounter globalizing forces, and how their particular cultural lenses shape the ways they choose to interact with those forces' (Lockwood 2003: 10).

In most instances, what motivates many customary landowning communities to engage in logging (or any large-scale natural resource development) is the potential financial benefit that it brings. Those who allow logging on their land often do not have access to other forms of income generation, or other forms of income generation are too labour intensive, they do not have readily accessible markets, and have relatively low returns. Hence, for them it makes perfect sense to allow the extraction of timber in return for rent, even if that rent makes up for only a small percentage of the value of the log on the international market. Indeed, for many customary landowners the resource rents from logging constitute amounts of money that they would otherwise never have access to, or would never be able to make producing copra or cocoa, etc.

Hence, for people who struggle daily to find money to pay for basic needs such as clothes, kerosene, salt, sugar, soap and school fees, the decision to allow logging on their land is a rational one. It allows them to have access to and enjoy the goods and services that the global economy has to offer.

One of the reasons why policies aimed at reducing logging and anti-logging campaigns have often failed is because they have not offered alternative sources of income generation. Alfred Ghiro from Central Makira, for example, accused NGOs such as the Makira Conservation Foundation of trying to stop logging in his area without providing people with alternative sources of income generation (SIBC News, January 18, 2006). Because of people's desire for goods and services offered by the global market economy, environmental conservation by itself is insufficient. It is easy to sit in an air-conditioned office, enjoy all the trappings of the global market economy, and tell people who struggle daily to find money to pay for basic needs that they should not sell their forests.

In contemporary Solomon Islands societies the cash economy has become an important part of people's livelihood, and land, along with resources such as forests, often provides the only means to have access to it. This was, for example, aptly put by Enoch Sila from North Choiseul: 'Lan ia sapos hemi stap nating, bae iumi no garem selen long hem i $a^{\prime}$ (If the land stays idle, we will have no money 
from it) (Personal conversation, April 14, 1998). Land is therefore important, not only in the traditional sense as a source of food and a place of residence and identity, but as a potential source of income.

Another interesting development has been how local societies transform in order to accommodate logging and the money that it brings. Logging companies search for landowners for purposes of negotiating timber rights, and for the legal and corporate structures they need. They often expect landowning entities to fit into those structures. This influences landowning entities and how they organise themselves. Fa' anunu (unpublished) discusses how in North New Georgia, the Christian Fellowship Church organises its members into 'blokos' (blocks) as the social basis for planting and owning trees in forestry plantations. She explores whether this means changes in land tenure and, if so, how they work. Hviding (2000) discusses how the social changes associated with forestry in North New Georgia centre on the Christian Fellowship Church and the traditional butu butu (tribes), and how that has proven to produce positive outcomes in terms of the community's ability to provide social services - education and health - for its members.

In some cases landowning groups have formed themselves into 'companies' to resemble the corporate industries that they are dealing with. Consequently, from the mid-1980s, we have seen the establishment of 'local companies'. In 2005, for example, there were about 24 foreign companies, or contractors, working under contractual agreements with about 89 'local companies', or licence holders. The formation of local companies has important implications for how landowning entities organise themselves. First, the structured nature of companies creates hierarchies and immediately excludes certain people, especially women and youth, from the affairs of the community. It is often the case that big-men and those who are formally educated take on active roles, and in time dominate the affairs of the landowning group, or local company. This influences the way in which the community relates to the land and to each other.

These changes in social organisation surrounding land are not unique to Solomon Islands, or to the forestry industry, and do not necessarily mean that they are 'inauthentic', or 'unMelanesian'. Rather, they are interesting local reactions to the involvement of corporate powers in natural-resource development. Ernst (1999), Filer (1998) and Golub (2004) have discussed how mining triggered social changes and definitions of landowning groups in PNG.

In many cases, the demand for land and the injection of logging money often unwraps the complexities of local communities. As I said earlier, landowning communities are rarely homogeneous entities. They are made up of a dynamic group of people who have varying backgrounds, opinions and interests. Enoch Sila, a big-man of the Sarabani landowning group in North Choiseul, for example, said that his decision to sign a timber rights agreement was influenced not only 
by the Eagon Resources Development Company (SI) Ltd's promise that 'sapos iu givim kambani lan blong iu bae iu wanpala rich man' (if you give your land to the company you will become a rich man), but because of pressure from other members of the landowning group. As Sila stated in March 1998:

... olketa wantok blong mi tu ... Olketa sei, ei, bos, ma olketa olo olo blong iumi olketa onim lan ia olketa olo pinis ia. Ma sampala kolsap dae. Taem olketa dae hu nao bae tekem seleni. Ating gud chanisi olketa stil laev. Mekem olketa olo olo blong iumi tekem lelebet seleni bipoa olketa dae. Den mi sei, Oh no! nomoa nao! Olketa se nomoa iumi go. So, mipala go saenim (... it was my wantoks [relatives] who said, 'Hey boss, our elders who own the land are now very old. Some of them are about to die. If they die, who is going to take the money? It's good they are still alive so that they receive some money before they die.' I said, 'Oh, no! No!' But they said, 'Let's go.' So, we went and signed. (Interview, March 17, 1998)

This highlights the debates that go on within landowning groups and how decisions are made. In other cases decisions were made by a few who were able to exert control over the landowning company. In these instances, it often incites disharmony, as illustrated in the case of Lokuru on Rendova in the documentary film Since the Company Came. Much of the discontent within landowning groups often centres on the distribution of income, especially in cases where the big-man or those with formal education benefit more than women and the rest of the community.

Further, those who control the 'local companies' and the incomes accrued from royalty payments often become powerful individuals, creating new power dynamics within the community. We see the traditional big-man's position being challenged, very often by younger and formally educated individuals who are more knowledgeable about the world outside of the local communities. One could argue that there is nothing new in the emergence of new big-men who challenge existing ones. That is the nature of politics in many Melanesian societies. The difference, however, is that the power of the new big-men is derived from the existence of logging operations and their accumulation of wealth from it. It is, therefore, often not in their interest to see the logging companies go, or the wealth from logging distributed equitably among members of the landowning group.

Logging money could also create dependency and reduce economic productivity because the landowning community becomes so dependent on logging rent it simply sits and waits for the money. The local saying 'lif blong akwa nomoa tok' (it is the leaf of the akwa tree that talks) implies that one does not have to work, but simply wait for money to come from logging rent - for money to fall from the trees.

Much of the discussion on forestry centres on the State, logging companies and the mismanagement of logging money. It is also true, however, that some of the 
money from logging is often used for traditional social obligations, or for individuals to establish themselves as big-men. Hence, from a capitalist point of view, such money has been misused because it is not invested. For the Solomon Islander, however, the money has been used to lubricate social relations and fulfil traditional obligations. This is an example of how global capital is used for local purposes. Of course, this was not always the case, and it is also true that income from logging is often misused.

\section{Conclusions}

What does the story of the Solomon Islands forestry industry tell us about the interaction between global capital and local communities? Are local communities simply victims of globalisation? What motivates local communities to participate in large-scale natural resource developments such as logging?

First, transnational corporations will continue to be important in the development of natural resources in developing countries such as Solomon Islands. This is something that some of us might detest, but the realities are such that it is unlikely that the role of transnational corporations will diminish. Many local communities even in remote parts of the world are already connected to the global network of resources, capital, production and markets.

This, however, does not mean that local communities are simply passive victims of global forces. Indeed, in many cases, as we have seen in the case of the Solomon Islands forestry industry, local communities have attempted to mobilise and strategise in order to maximise their benefits from globalisation. They have their own motives for getting involved, which might vary between as well as within communities.

Second, it is useful to note that the ability of local communities to benefit from their dealings with transnational corporations varies from community to community depending on that community's capacity to deal with global forces. It might, therefore, be unrealistic to shut off globalisation and throw its evil over the edge of the Earth. Rather, it might be more useful to build and strengthen the capacity of local communities to deal with global forces, forms and processes.

\section{References}

Asian Development Bank. 1998. 'Solomon Islands, 1997 Economic Report.' Pacific Studies Series. Manila: Asian Development Bank.

Aspire Films, 1996. Advertising Missionaries. Aspire Films and Ellipse Program. Produced by ABC Australia and France 3, RTSR in association with the Australian Film Finance Corporation and the Centre National de la Cinematographie. New York: First Run/Icarus Films. 
AusAID. 1999. Solomon Islands Forestry Management Project: Feasibility Study Report and Project Design Document. Prepared for AusAID and Solomon Islands Government Rural Development Group. Canberra: AusAID.

Auty, Richard M. 1993. Sustaining Development in Mineral Economies: The Resource Curse Thesis. London and New York: Routledge.

Bennett, Judith A. 2000a. 'Grievous Mistake of the Vanikoro Concession: The Vanikoro Kauri Timber Company, Solomon Islands, 1926-1964.' Environment and History, 6. pp. 317-47.

Bennett, Judith A. 2000b. Pacific Forest: A history of resource control and contest in Solomon Islands, c. 1800-1997. Cambridge: The White Horse Press.

Central Bank of Solomon Islands. 1996. CBSI Annual Report 1995. Honiara.

Central Bank of Solomon Islands. 1998. CBSI Annual Report 1997. Honiara.

Central Bank of Solomon Islands. 1999. CBSI Annual Report 1998. Honiara.

Central Bank of Solomon Islands. 2000. CBSI Annual Report 1999. Honiara.

Diamond, Jared. 1999. Guns, Germs, and Steel: The Fate of Human Societies. New York: W. W. Norton and Company.

Dauvergne, Peter. 1998-99. 'Corporate Power in the Forests of the Solomon Islands.' Pacific Affairs, 71, 4. pp. 524-46.

Dauvergne, Peter. 2001. Loggers and Degradation in the Asia-Pacific: Corporation and Environmental Management. New York: Cambridge University Press. de Gregorio, Jose. 2002. 'The Role of Foreign Direct Investment and Natural Resources in Economic Development.' Central Bank of Chile, Working Papers, No. 196, January 2003, http://www.bcentral.cl/Estudios/DTBC/doctrab.htm (accessed December 7, 2005).

Duncan, Ron. 1994. 'Melanesian Forestry Sector Study.' International Development Issues, No. 36. Canberra: AIDAB.

Ernst, Thomas. 1999. 'Land, Stories, and Resources: Discourse and Entification in Onabusulu Modernity.' American Anthropologist, 101, 1. pp. 88-97.

Fa'anunu, Kalisi. Unpublished. 'Christian Fellowship Church Reforestation: A Change in Customary Land Tenure in the Solomon Islands?'

Filer, Colin. 1997. 'Resource Rents.' In Illa Temu (ed.), Papua New Guinea: A 20/20 Vision?, Canberra: NCDS.

Filer, Colin. 1998. 'The Melanesian Way of Menacing the Mining Industry.' In L. Zimmer-Tamakoshi (ed.), Modern Papua New Guinea, Kirksville: Thomas Jefferson University Press. 
Firth, Stewart. 2000. 'The Pacific Islands and the globalization agenda.' The Contemporary Pacific, 12, 1. pp. 178-92.

Foale, Simon and Martha MacIntyre. 1999. 'Dynamic and Flexible Aspects of Land and Marine Tenure at West Nggela: Implications for Marine Resource Management.' Oceania, 71, 1. pp. 30-45.

FORTECH. 1995. 'Report of Visit to Japan and Korea by TCUP Commercial Unit Manager and CBSI Foreign Exchange Manager, 26 March-8 April 1995 (by S. Mulholland and G. Simbe).' Timber Control Unit Project Report, No. 18. Canberra: AIDAB.

Fraenkel, Jon. 2004. The Manipulation of Custom: From Uprising to Intervention in the Solomon Islands. Wellington: Victoria University Press.

Frazer, Ian. 1997a. 'The Struggle for Control of Solomon Islands Forests.' The Contemporary Pacific, 9, 1. pp. 39-72.

Frazer, Ian. 1997b. 'Resource Extraction and the Post-colonial State in Solomon Islands.' In R. F. Watters and T. G. McGee (eds), Asia Pacific: New Geographies of the Pacific Rim, London: Routledge.

Gerritsen, Rolf and Martha MacIntyre. 1991. 'Dilemmas of Distribution: The Misima Gold Mine, Papua New Guinea.' In J. Connell and R. Howitt (eds), Mining and Indigenous Peoples in Australasia, Sydney: Sydney University Press. pp. 34-53.

Golub, Alex. 2004. 'Making the Ipili Feasible: Imagining Local and Global Actors at the Porgera Mine, Enga Province, Papua New Guinea.' PhD dissertation, University of Chicago.

Gosarevski, S., H. Hughes and S. Windybank. 2004. 'Is Papua New Guinea viable with customary land ownership?' Pacific Economic Bulletin, 19, 3. pp. 133-6.

Hannerz, Ulf. 1997. 'Scenarios for Peripheral Cultures.' In Anthony King (ed.), Culture, Globalisation and the World System: Contemporary Conditions for the Representation of Identity, Minneapolis: University of Minnesota Press. pp. 107-28.

Horton, James Oliver and Lois E. Horton. 2005. Slavery and the Making of America. New York: Oxford University Press.

Hviding, Edvard and Tim Bayliss-Smith. 2000. Islands of Rainforest: Agroforestry, logging and eco-tourism in Solomon Islands. UK: Ashgate Publishing.

Kotch, Nick. 2005. 'African Oil: Whose Bonanza?' National Geographic Magazine - Africa: Whatever You Thought, Think Again, Special Issue, September 2005. pp. 50-65. 
Lal, Brij V. 2004. Girmitiyas: The Origins of the Fiji Indians. Lautoka: Fiji Institute of Applied Studies.

Lockwood, Victoria S. (ed.) 2003. Globalisation and Culture Change in the Pacific Islands. New Jersey: Prentice Hall.

Makim, Abigail. 2002. 'Globalisation, Community Development, and Melanesia: The North New Georgia Sustainable Social Forestry and Rural Development Project.' SSGM Discussion Paper 02/1. Canberra: ANU.

Montgomery, Phillip. 1995. 'Forestry in Solomon Islands.' Pacific Economic Bulletin, 10, 2. pp. 74-6.

Mintz, Sidney W. 1995. Sweetness and Power: The Place of Sugar in Modern History. New York: Penguin Books.

Moore, Clive. 2005. Happy Isles in Crisis: The Historical Causes for a Failing State in Solomon Islands, 1998-2004. Canberra: Asia Pacific Press.

Moore, Clive, Jacqueline Leckie and Doug Munro (eds) 1990. Labour in the South Pacific. Townsville: James Cook University.

Price Waterhouse. 1995. Final Draft Report - Forestry Taxation and Domestic Processing Study. Honiara: Ministry of Finance and Ministry of Forests, Environment and Conservation.

Ross, Michael L. 2001. Timber Booms and Institutional Breakdown in Southeast Asia. Cambridge: Cambridge University Press.

Sheehan, Peter. 2000. 'Solomon Islands economic and governance update on forests sector.' Paper presented to SICHE/ANU Solomon Islands Economic and Governance Update, Solomon Islands College of Higher Education, Honiara, March 16-17.

Solomon Star, November 14 and 17, 2005, January 29, 1997, April 2, 1996.

Tausinga, Job Duddley. 1989. 'Logging in North New Georgia Timber Corporation (NNGTC).' In Ron Crocombe et al. (eds), Independence, Dependence, Interdependence: The First 10 years of Solomon Islands Independence, Suva and Honiara: Institute of Pacific Studies with the University of the South Pacific, Honiara Centre and the Solomon Islands College of Higher Education. pp. 55-66.

Tiensten, Paul. 2001. 'Gas Commercialisation: Efforts to Secure PNG's Economic Future.' http://www.pomcci.org.pg/hiri2001/Tiensten.doc (accessed on February 9, 2006).

Turia, Ruth C. H. 2003. 'Efficient Management of Forest Resources.' In David Kavanamur, Charles Yala and Quinton Clements (eds), Building a Nation in Papua New Guinea: Views of the Post-Independence Generation, Canberra: Pandanus Books. pp. 183-97. 